\title{
PENGARUH KEPEMIMPINAN TRANSFORMASIONAL, ETOS KERJA DAN KOMPETENSI TERHADAP KINERJA GURU (STUDI PADA YAYASAN TARBIYATUL ISLAM NW WANASABA LOMBOK TIMUR)
}

\author{
L1. Abd. Hafidz ${ }^{1}$, Agusdin ${ }^{2}$, Hermanto ${ }^{3}$ \\ ${ }^{1}$ Magister Manajemen FEB Unram. E-mail: hafidzmahrim@gmail.com \\ 2Fakultas Ekonomi dan Bisnis Unram. E-mail: dragusdin@gmail.com \\ 3Fakultas Ekonomi dan Bisnis Unram. E-mail: hermanto2307@gmail.com
}

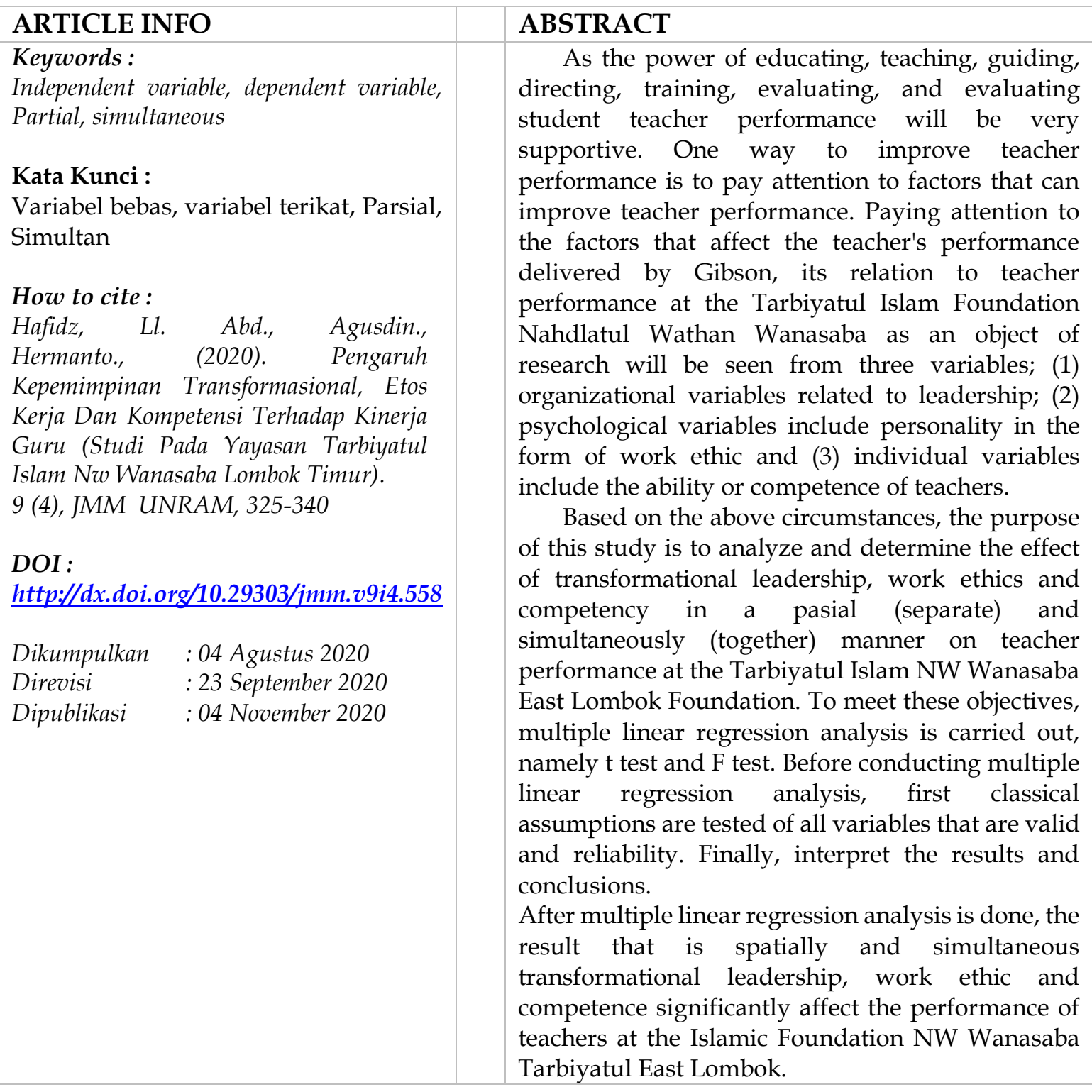




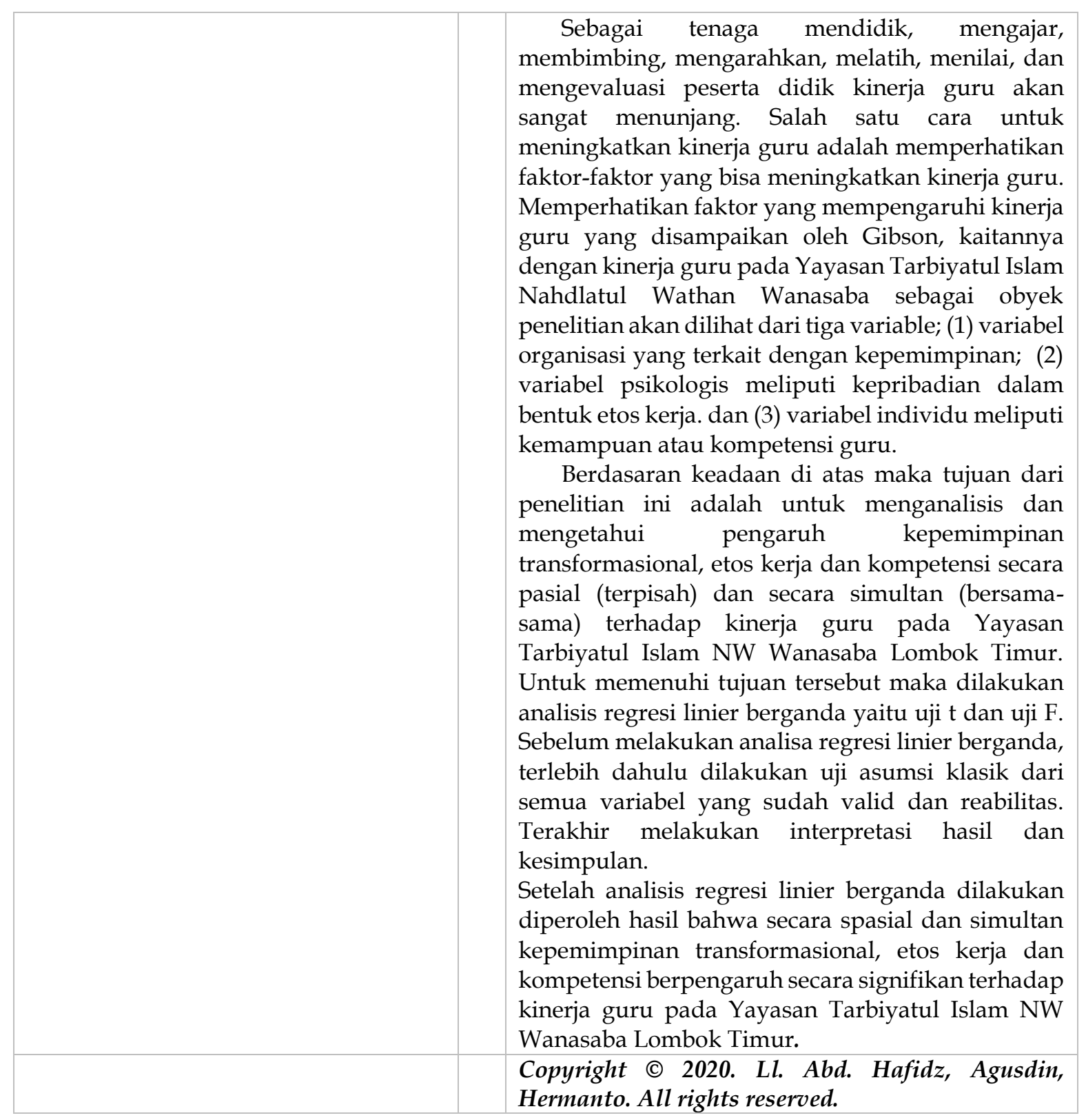

\section{PENDAHULUAN}

Organisasi sekolah adalah sebuah perserikatan di bawah manajemen sekolah yang bertujuan untuk membantu menciptakan sebuah kondisi yang efektif dari kegiatan sekolah ( Priansa, 2014:43). Salah satu elemen pokok dalam organisasi sekolah guru. Hal ini sesuai dengan Undang-Undang Republik Indonesia N0 14 Tahun 2005 tentang Guru dan Dosen Pasal 1 ayat (1) menyatakan bahwa: Guru adalah pendidik profesional dengan tugas utama mendidik, mengajar, membimbing, mengarahkan, melatih, menilai, dan mengevaluasi peserta didik pada pendidikan anak usia dini jalur pendidikan formal, pendidikan dasar, dan pendidikan menengah.

Yayasan Tarbiyatul Islam NW Wanasaba merupakan salah satu lembaga pendidikan atau sekolah yang ada di Nusa Tenggara Barat (NTB) dan memiliki beberapa jenjang pendidikan. Secara umum kepemimpinan Kepala Madrasah/Sekolah di lingkungan Yayasan Tarbiyatul Islam NW Wanasaba berjalan normal layaknya di semua organisasi atau 
lembaga harus ada pemimpinnya. Namun existensinya sebagai pemimpin lembaga dengan segala tugas dan fungsinya masih belum optimal. Kaitannya dengan etos kerja pada guruguru Yayasan Tarbiyatul Islam NW Wanasaba sesungguhnya telah didasari dengan nilai pengabdian. Artinya mengajar sebagai bentuk pengabdian, mengajar sebagai ibadah, mengajar sebagai panggilan jiwa, mengajar sebagai bentuk pelayanan itu sejalan dengan spirit dalam gerak perjuangan Yayasan Tarbiyatul Islam NW Wanasaba. Fenomena yang ada saat ini spirit perjuangan mulai tergeser dengan nilai-nilai yang bersifat pragmatis. Orientasi guru tidak lagi mengajar sebagai bentuk pengabdian saja, tapi mengharapkan insentif dari kerja yang telah dilakukan, seperti honor terstandarisasi dengan baik, harapan dan jaminan mendapatkan sertifikasi guru dan atau untuk mencukupkan jam bagi yang sudah berstatus guru sertifikasi di lembaga pendidikan yang lain. Standarisasi guru pada Yayasan Tarbiyatul Islam NW Wanasaba tergolong memadai namun dari segi kompetensi guru masih sedang, hal ini tergambar dari jumlah guru yang tersertifikasi masih 48 orang setara dengan $33,33 \%$ sementara yang belum tersertifikasi sebanyak 96 orang atau setara dengan $66,67 \%$. Disamping itu juga masih banyak guru yang mengajar tidak sesuai dengan disiplin keilmuannya (Sumber : Yayasan Tarbiyatul Islam NW Wanasaba Lombok Timur).

Menurut Gibson., at al (1985:51-53) dalam Supardi (2012:19) kinerja guru dipengaruhi oleh tiga kelompok variabel, yaitu : pertama variabel individu meliputi kemampuan dan keterampilan fisik (dalam hal ini kemampuan dan keterampilan memahami kurikulum), latar belakang (keluarga tingkat sosial, pengalaman), demokratis (umur, etnis, jenis kelamin). Kedua variabel organisasi meliputi sumber daya, kepemimpinan, imbalan, struktur, desain organisasi. Ketiga variabel psikologis meliputi persepsi, sikap, kepribadian, belajar, motivasi, kepuasan kerja, iklim kerja.

Beberapa penelitian empiris telah menemukan bahwa kepemimpinan transformasional berpengaruh terhadap peningkatan kinerja guru. Seperti hasil penelitian Heryana M., (2015), Rustamaji, ACP., at al (2017), Yusuf, D.U., (2017), Suhada, at al (2019), Azizah N., at al (2019), Wote, AYV., at al (2019) yang menemukan bahwa kepemimpinan transformasional berpengaruh positif dan signifikan terhadap kinerja guru. Sedangkan penelitian telah menemukan bahwa etos kerja mempengaruhi kinerja guru seperti hasil penelitian Hakim, H (2017), Putra, CAA., at al (2017), Sujana I.K., at al (2018), Marlina (2019), Ismawantini, NKL., at al (2019), Fairy, SNPO., at al (2019), Muliartini, N.M., at al (2019), Waang M, et al., (2019). Selain faktor Kepemimpinan dan etos kerja, factor lain yang mempengaruhi kinerja adalah kompetensi. Beberapa penelitian telah menemukan bahwa kompetensi berkontribusi dalam meningkatkan kinerja seperti penelitian Turangan (2017), Aminatuzzuhro (2017), Nurdianti (2017), Hudayati (2018), Suandi (2018), Heriswanto (2018) dan Patarai, et al., (2018) yang dalam penelitiannya menemukan bahwa terdapat pengaruh yang positif dan signifikan antara kompetensi terhadap kinerja guru.

Memperhatikan faktor yang mempengaruhi kinerja yang disampaikan oleh Gibson dan beberapa fakta empiris tersebut di atas, maka penelitian ini menjadi penting dan berusaha mengungkapkan pengaruh kepemimpinan transformasional, etos kerja dan kompetensi terhadap kinerja guru. Penelitian dilaksanakan di Yayasan Tarbiyatul Islam Nahdlatul Wathan Wanasaba dengan judul "Pengaruh Kepemimpinan Transformasional, Etos Kerja dan Kompetensi terhadap Kinerja Guru (Study pada Yayasan Tarbiyatul Islam NW Wanasaba Lombok Timur). Penelitian ini bertujuan untuk menganalisis pengaruh kepemimpinan transformasional, etos kerja dan kompetensi terhadap kinerja guru pada Yayasan Tarbiyatul Islam NW Wanasaba Lombok Timur.

\section{TINJAUAN PUSTAKA}


Kepemimpinan transformasional merupakan proses dimana orang terlibat dengan orang lain, dan menciptakan hubungan yang meningkatkan motivasi dan moralitas dalam diri pemimpin dan pengikut. Jenis pemimpin ini memiliki perhatian pada kebutuhan dan motif pengikut, serta mencoba membantu pengikut mencapai potensi terbaik mereka (Northouse, 2013). Seorang pemimpin dikatakan transformasional diukur dari tingkat kepercayaan, kepatuhan, kekaguman, kesetiaan dan rasa hormat para pengikutnya (Karim, 2010;20).

Berdasarkan penelitian Hasel dan Bram (dalam Keller (1992), sailana (2005), dan atmojo (2018)) menemukan para pemimpin yang menerapkan gaya kepemimpinan trasformasional menghasilkan kerja yang jauh lebih tinggi dibandingkan dengan pemimpin yang tidak menerapkan kepemimpinan transformasional. Sedangkan Suyanto (2001) berpendapat bahwa seorang kepala sekolah perlu mengadopsi gaya kepemimpinan transformasional karena mampu meningkatkan kinerja guru. Hal ini sejalan dengan penelitian Tokhibin \& Wuradji, (2013), Heryana (2015), Yuliati (2015), Yusuf (2017), dan Rustamaji (2017) yang menemukan bahwa kepemimpinan transformasional berpengaruh positif dan signifikan terhadap kinerja guru.

Tasmara (2002) etos kerja adalah totalitas kepribadian dirinya serta caranya mengekspresikan, memandang, meyakini dan memberikan makna ada sesuatu, yang mendorong dirinya untuk bertindak dan meraih amal yang optimal sehingga pola hubungan antara manusia dengan dirinya dan antara manusia dengan makhluk lainnya dapat terjalin dengan baik.

Etos kerja guru merupakan semangat kerja yang harus dimiliki oleh guru guna keberhasilannya. Memiliki etos kerja yang tinggi akan mempengaruhi kinerja guru yang sesuai dengan yang diharapkan. Sukardewi, et al., (2013) dalam penelitiannya di SMA negeri di Kota Amlapura menunjukkan bahwa etos kerja berpengaruh signifikan terhadap kinerja guru. Hal ini sejalan dengan penelitian yang dilakukan oleh Wiriani, et al., (2013) putra et.al., (2013) Hakim (2017), Waang et.al., (2019) dan Marlina (2019) yang menemukan bahwa etos kerja berpengaruh signifikan terhadap kinerja.

Menurut Wibowo $(2014 ; 271)$ Kompetensi adalah suatu kemampuan untuk melaksanakan atau melakukan pekerjaan atau tugas yang dilandasi atas keterampilan dan pengetahuan serta didukung oleh sikap kerja yang dituntut oleh pekerjaan tersebut

Penelitian yang dilakukan oleh Turangan (2017) di SMA Negeri 1 Manado Hasil penelitian ini menemukan bahwa terdapat kontribusi yang positif dan signifikan antara kompetensi berpengaruh signifikan terhadap kinerja guru.. Hal ini sejalan dengan hasil penelitian yang dilakukan oleh Aminatuzzuhro (2017), Nurdianti (2017), Hidayati (2018), Suandi (2018), Heriswanto (2018) dan Patarai at.al (2016) yang dalam penelitiannya menemukan bahwa terdapat hubungan yang positif dan signifikan antara kompetensi terhadap kinerja kinerja guru.

Uji $t$ pada dasarnya menunjukkan seberapa jauh pengaruh satu variabel independent (X) secara individual dalam menerangkan variasi variabel dependent (Y) (Ghozali, 2001). Langkah-langkah Uji Hipotesis untuk Koefisien Regresi adalah:

Perumusan Hipotesis Nihil $\left(\mathrm{H}_{0}\right)$ dan Hipotesis Alternatif $\left(\mathrm{H}_{1}\right)$

1. $\mathrm{H}_{0}: \beta_{1}=0$

Tidak ada pengaruh yang signifikan dari masing-masing variabel bebas $\left(\mathrm{X}_{1}, \mathrm{X}_{2}, \mathrm{X}_{3}\right)$ terhadap variabel terikat $(Y)$.

2. $\mathrm{H}_{1}: \beta_{0} \neq 0$

Ada pengaruh yang signifikan dari masing-masing variabel bebas $\left(\mathrm{X}_{1}, \mathrm{X}_{2}, \mathrm{X}_{3}\right)$ terhadap variabel terikat $(\mathrm{Y})$. 
NATIONALLY ACCREDITED JOURNAL - DECREE NO. 21/E/KPT/2018

Sedangkan untuk mengetahui hubungan antara variabel independent $(X)$ dan variabel dependent $(\mathrm{Y})$, secara simultan (bersama-sama) terhadap variabel dependent $(\mathrm{Y})$ dapat dilakukan dengan menggunakan uji $F$. 
Langkah-langkah pengujiannya adalah sebagai berikut (Ghozali, 2005)

a. Menentukan Formulasi Hipotesis

- $\mathrm{H}_{0}: \beta_{1}=\beta_{2}=0$, artinya variabel $X_{1}, X_{2}, X_{3}, X_{4}$ dan $X_{5}$ tidak mempunyai pengaruh yang signifikan secara simultan terhadap variabel $Y$.

- $\mathrm{H}_{1}: \beta_{1}=\beta_{2} \neq 0$, artinya variabel $X_{1}, X_{2}, X_{3}, X_{4}$ dan $X_{5}$ mempunyai pengaruh yang signifikan secara simultan terhadap variabel $\mathrm{Y}$.

b. Menentukan derajat kepercayaan $95 \%(\alpha=0,05)$.

c. Menentukan signifikansi dan Membuat kesimpulan

- Bila $(P$ Value $)<0,05$ maka $\mathrm{H}_{0}$ ditolak dan Ha diterima. Artinya variabel independent $(X)$ secara simultan (bersama-sama) mempengaruhi variabel dependent $(\mathrm{Y})$.

- Bila $(P$ Value $)>0,05$ maka $\mathrm{H}_{0}$ diterima dan Ha ditolak. Artinya variabel independent $(X)$ secara simultan (bersama-sama) tidak mempengaruhi variabel dependent (Y).

\section{METODOLOGI PENELITIAN}

\section{A. Jenis Penelitian}

Penelitian ini adalah penelitian kuantitatif yaitu penelitian dengan memperoleh data yang berbentuk angka dan di analisis menggunakan statistik. Berdasarkan tingkat eksplanasi, penelitian ini termasuk jenis penelitian asosiatif kausal yaitu penelitian yang mengkaji hubungan yang bersifat sebab akibat, dimana ada variable independen (variable yang mempengaruhi) dan dependen (variable yang dipengaruhi). (Sugiyono, 2018:37)

\section{B. Populasi dan Responden Penelitian}

Populasi dalam penelitian ini adalah seluruh guru pada Yayasan Tarbiyatul Islam Nahdlatul Wathan Wanasaba Kec. Wanasaba Kabupaten Lombok Timur Prov, Nusa Tenggara Barat. Jumlah Populasi dalam penelitian ini adalah sebanyak 144 orang guru dengan rincian sebagai berikut.

Tabel 1. Jumlah Populasi

\begin{tabular}{|c|l|c|}
\hline No. & \multicolumn{1}{|c|}{ Satuan Pendidikan } & Jumlah Populasi \\
\hline 1. & TK TI NW Wanasaba & $\mathbf{9}$ \\
\hline 2. & MI NW No 2 Wanasaba & $\mathbf{1 7}$ \\
\hline 3. & SDI TI NW Wanasaba & $\mathbf{1 2}$ \\
\hline 4. & MTs NW Wanasaba & $\mathbf{2 4}$ \\
\hline 5. & SMP NW Wanasaba & $\mathbf{2 5}$ \\
\hline 6. & MA NW Wanasaba & $\mathbf{2 4}$ \\
\hline 7. & SMA NW Wanasaba & $\mathbf{1 6}$ \\
\hline 8. & SMK NW Wanasaba & $\mathbf{1 7}$ \\
\hline \multicolumn{2}{|c|}{ Jumlah } & $\mathbf{1 4 4}$ \\
\hline
\end{tabular}

Sumber: Yayasan Tarbiyatul Islam NW Wanasaba Lombok Timur

Pada penelitian ini teknik sampling yang digunakan adalah nonprobability sampling dengan teknik sampling jenuh/sensus. Sugiono, (2018:85) mendifinisikan sampling jenuh/sensus adalah teknik penentuan sampel bila semua anggota populasi digunakan sebagai sampel. Hal ini sering dilakukan bila jumlah populasi, kurang dari 30 orang, atau penelitian yang ingin membuat generalisasi dengan kesalahan yang sangat kecil dalam penelitian relatif kecil. Jadi, semua populasi sebanyak 144 orang guru menjadi sampel dalam penelitian ini. 


\section{Jenis Data dan Sumber Data}

Data pada penelitian ini terdiri atas 2 jenis data yaitu :

1. Data kuantitatif dalam penelitian ini antara lain jumlah guru, data kuesioner, dan lai-lain di Yayasan Tarbiyatul Islam NW Wanasaba Lombok Timur.

2. Data kualitatif terdiri dari nama responden, pendidikan dan lain-lain di Yayasan Tarbiyatul Islam NW Wanasaba Lombok Timur.

Data tersebut diambil dari 2 sumber data yaitu :

1. Data primer yaitu data yang diperoleh langsung dari responden penelitian dalam hal ini adalah jawaban para guru Yayasan Tarbiyatul Islam NW Wanasaba Lombok Timur.

2. Data sekunder yaitu data yang diperoleh dari buku, majalah, jurnal-jurnal, internet dan dokumen lainnya yang ada hubungannya dengan materi kajian seperti struktur organisasi, jumlah guru Yayasan Tarbiyatul Islam NW Wanasaba Lombok Timur.

\section{Teknik dan Alat Pengumpulan Data}

Data yang digunakan pada penelitian ini diperoleh dengan menggunakan teknik dan alat pengumpulan data sebagai berikut.

1. Wawancara/ interview yaitu melalui diskusi dan tanya jawab secara langsung terhadap guru Yayasan Tarbiyatul Islam NW Wanasaba Lombok Timur.

2. Angket (kuesioner) yaitu melakukan penyebaran kuesioner terkait beberapa indikator dalam pelaksanaan kepemimpinan transformasional, etos kerja, kompetensi dan kinerja guru pada Yayasan Tarbiyatul Islam NW Wanasaba Lombok Timur.

3. Observasi, yaitu melakukan pengamatan langsung terhadap pelaksanaan kepemimpinan transformasional, etos kerja, kompetensi dan kinerja guru pada Yayasan Tarbiyatul Islam NW Wanasaba Lombok Timur.

\section{E. Variabel Penelitian}

Variabel yang digunakan pada penetian ini terdiri :

1. Variabel independent terdiri dari Kepemimpin Transformasional $\left(X_{1}\right)$, Etos Kerja $\left(X_{2}\right)$ dan Kompetensi $\left(\mathrm{X}_{3}\right)$;

2. Variabel dependent yang dalam penelitian ini adalah Kinerja Guru $(Y)$.

Masing-masing variabel terdiri dari beberapa indikator. Indikator dari masingmasing variabel di tunjukkan pada Tabel 2.

Tabel 2. Indikator dari masing-masing variabel

\begin{tabular}{cl}
\hline Variabel Kepemimpinan Transformasional \\
\hline Variabel & \multicolumn{1}{c}{ Keterangan Variabel } \\
$\mathbf{X}_{\mathbf{1 1}}$ & Idealized Influence (Pengaruh Ideal) \\
$\mathrm{X}_{111}$ & Kharismatik \\
$\mathrm{X}_{112}$ & Meyakinkan \\
$\mathrm{X}_{113}$ & Membanggakan \\
$\mathrm{X}_{114}$ & Memiliki kapasitas dalam mengatasi \\
& setiap permasalahan \\
& Mendahulukan kepentingan \\
$\mathrm{X}_{115}$ & organisasi dan kepentingan orang lain \\
& daripada kepentingan peribadi \\
& Memberikan visi dan misi pekerjaan \\
\hline $\mathbf{X}_{\mathbf{1 2}}$ & $\begin{array}{l}\text { Inspirational Motivation (Motivasi } \\
\text { Inspirasional) }\end{array}$ \\
\hline
\end{tabular}




\begin{tabular}{|c|c|}
\hline$X_{121}$ & $\begin{array}{l}\text { Menyampaikan visi dan misi secara } \\
\text { menarik }\end{array}$ \\
\hline$X_{122}$ & $\begin{array}{l}\text { Menginsptrasi bawahan dalam } \\
\text { mencapai tujuan }\end{array}$ \\
\hline$X_{13}$ & $\begin{array}{l}\text { Intellectual Stimulation (Stimulasi } \\
\text { Intelektual) }\end{array}$ \\
\hline $\mathrm{X}_{131}$ & $\begin{array}{l}\text { Mampu dalam meningkatkan } \\
\text { kecerdasan untuk meningkatkan } \\
\text { kreativitas dan inovasi bawahan }\end{array}$ \\
\hline$X_{132}$ & $\begin{array}{l}\text { Berusaha mendorong bawahan untuk } \\
\text { memikirkan kembali cara kerja }\end{array}$ \\
\hline $\mathrm{X}_{133}$ & $\begin{array}{l}\text { Berusaha mendorong bawahan untuk } \\
\text { mencari cara-cara kerja baru dalam } \\
\text { menyelesaikan tugasnya }\end{array}$ \\
\hline$X_{14}$ & $\begin{array}{l}\text { Individualized Consideration } \\
\text { (Pertimbangan Individual) }\end{array}$ \\
\hline $\mathrm{X}_{141}$ & $\begin{array}{l}\text { Berusaha memberikan perhatian } \\
\text { kepada bawahan }\end{array}$ \\
\hline$X_{142}$ & $\begin{array}{l}\text { Menghargai sikap bawahan terhadap } \\
\text { organisasi }\end{array}$ \\
\hline $\mathrm{X}_{143}$ & Memberikan saran \\
\hline $\mathrm{X}_{144}$ & Memberi peluang \\
\hline \multicolumn{2}{|r|}{ Variabel Etos Kerja Guru } \\
\hline Variabel & Keterangan Variabel \\
\hline $\mathrm{X}_{21}$ & Kerja adalah rahmat \\
\hline$X_{22}$ & Kerja adalah amanah \\
\hline$X_{23}$ & Kerja adalah panggilan \\
\hline $\mathrm{X}_{24}$ & Kerja adalah aktualisasi \\
\hline $\mathrm{X}_{25}$ & Kerja adalah ibadah \\
\hline$X_{26}$ & Kerja adalah seni \\
\hline$X_{27}$ & Kerja adalah kehormatan \\
\hline$X_{28}$ & Kerja adalah pelayanan \\
\hline \multicolumn{2}{|r|}{ Variabel Kompetensi } \\
\hline Variabel & Keterangan Variabel \\
\hline $\mathrm{X}_{31}$ & Kompetensi Pedagogik \\
\hline$X_{32}$ & Kompetensi Kepribadian \\
\hline$X_{33}$ & Kompetensi Profesional \\
\hline$X_{34}$ & Kompetensi Sosial \\
\hline \multicolumn{2}{|r|}{ Variabel Kinerja Guru } \\
\hline Variabel & Keterangan Variabel \\
\hline$Y_{1}$ & $\begin{array}{l}\text { Kemampuan menyusun rencana } \\
\text { pembelajaran }\end{array}$ \\
\hline $\mathrm{Y}_{2}$ & $\begin{array}{l}\text { Kemampuan melaksanakan } \\
\text { pembelajaran }\end{array}$ \\
\hline $\mathrm{Y}_{3}$ & $\begin{array}{l}\text { Kemampuan mengadakan hubungan } \\
\text { antarpribadi }\end{array}$ \\
\hline $\mathrm{Y}_{4}$ & $\begin{array}{l}\text { Kemampuan melaksanakan penilaian } \\
\text { hasil belajar }\end{array}$ \\
\hline $\mathrm{Y}_{5}$ & $\begin{array}{l}\text { Kemampuan melaksanakan } \\
\text { pengayaan }\end{array}$ \\
\hline$Y_{6}$ & Kemampuan melaksanakan remedial \\
\hline
\end{tabular}




\section{F. Metode Penelitian} berikut:

Dalam mencapai tujuan pada penelitian ini dilakukan langkah-langkah sebagai

1. Mendeskripsikan hasil nilai dari keempat variabel yang digunakan pada penelitian;

2. Melakukan Uji Validitas dan Reliabilitas;

3. Setelah Uji Validitas dan Reliabilitas terpenuhi langkah selanjutnya adalah Melakukan Uji Asumsi Klasik (Uji Normalitas, Uji Heteroskedastisitas, Uji Multikolinieritas, Uji Autokorelasi);

4. Jika semua Asumsi Klasik terpenuhi maka selanjutnya melakukan Analisis Regresi Linier Berganda yaitu Uji t dan Uji F;

5. Langkah terakhir yaitu interpretasi hasil dan kesimpulan.

Tahapan-tahapan di atas dilakukan secara otomatis oleh komputer dengan menggunakan Microsoft Excel dan software SPSS.

\section{HASIL DAN PEMBAHASAN}

\section{Deskripsi nilai dari keempat variabel}

Deskripsi mengenai variabel independen dan dependen pada penelitian ini ditunjukkan pada tabel 2. Dari deskripsi ini kita dapat melihat nilai dari keempat variabel yang digunakan pada penelitian ini.

Tabel 3. Deskripsi Data Penelitian

\begin{tabular}{|l|c|c|c|c|c|c|c|}
\hline \multicolumn{7}{|c|}{ Descriptive Statistics } \\
\hline & N & Range & Minimum & Maximum & Sum & Mean & $\begin{array}{c}\text { Std. } \\
\text { Deviation }\end{array}$ \\
\hline $\begin{array}{l}\text { Kepemimpinan } \\
\text { transformasional }\end{array}$ & 144 & 17 & 43 & 60 & 7488 & 52.00 & 4.081 \\
\hline Etos Kerja & 144 & 30 & 49 & 79 & 9366 & 65.04 & 6.244 \\
\hline Kompetensi & 144 & 27 & 60 & 87 & 10535 & 73.16 & 5.609 \\
\hline Kinerja Guru & 144 & 24 & 61 & 85 & 10479 & 72.77 & 5.144 \\
\hline
\end{tabular}

Tabel 3 menunjukkan bahwa sebaran nilai yang paling besar adalah etos kerja yaitu 30, dimana nilai minimumnya sebesar 49 dan maksimum sebesar 79. Jumlah total nilai etos kerja sebanyak 9366 dan rata-rata sebesar 65,04 dngan std deviasi sebesar 6,244. Sedangkan nilai dengan sebaran paling kecil adalah kepemimpinan transformasional. Hal ini dapat terlihat dari range lebih kecil dari variabel yang lain yaitu sebesar 17. Total nilai kepemimpinan transformasional sebanyak 7488 dan rata-rata sebesar 52,00 dengan std deviasi sebesar 4,081. Std deviasi ini paling kecil dibandingkan dengan variabel yang lain.

\section{Uji Validasi dan Reabilitas}

Setelah dilakukan uji validasi diperoleh nilai pearson correlation (nilai $r$ hitung) dari masing-masing item lebih besar dari nilai $r$ tabel $(0,159)$. Begitu juga dengan nilai probabilitas dari seluruh item menunjukkan tingkat signfikansi kurang dari 0,05. Dengan demikian seluruh item pernyataan pada variabel kepemimpinan transformasional, variabel etos kerja, variabel kompetensi dan variabel kinerja guru dinyatakan valid.

Pengujian masing-masing instrumen dilakukan dengan menggunakan rumus Cronbach Alpha sebagaimana dikatakan Nunnally (1967 dalam Ghozali, 2007), suatu konstruk atau variabel dikatakan reliabel jika memberikan nilai Cronbach Alpha $>0,60$. Adapun hasil uji reliabilitas nampak dalam tabel 4 . 
Tabel 4. Hasil Uji Reliabilitas

\begin{tabular}{|c|l|c|c|}
\hline No. & \multicolumn{1}{|c|}{ Variabel } & $\begin{array}{c}\text { Cronbach } \\
\text { Alpha }\end{array}$ & Kriteria \\
\hline 1. & $\begin{array}{l}\text { Kepemimpinan } \\
\text { Transformasional } \\
\left(\mathrm{X}_{1}\right)\end{array}$ & 0,741 & Reliabel \\
\hline 2. & Etos Kerja $\left(\mathrm{X}_{2}\right)$ & 0,759 & Reliabel \\
\hline 3. & Kompetensi $\left(\mathrm{X}_{3}\right)$ & 0,762 & Reliabel \\
\hline 4. & Kinerja Guru $(\mathrm{Y})$ & 0,736 & Reliabel \\
\hline
\end{tabular}

Dari tabel 4 terlihat bahwa nilai Crombach Alpha dari masing-masing varibel $>0,60$. Dengan demikian semua item variabel dapat dinyatakan reliabel.

\section{Uji Asumsi Klasik}

Model regresi linier berganda dapat dikatakan model yang baik (memiliki ketepatan dalam estimasi, tidak bias dan konsisten) jika model tersebut memenuhi uji asumsi klasik. Uji asumsi klasik terdiri dari uji normalitas, uji heteroskedatisitas, uji multikolinieritas, dan uji autokorelasi. Hasil uji asumsi klasik untuk analisis regresi berganda pada penelitian ini adalah sebagai berikut.

\subsection{Uji Normalitas}

Model regresi memenuhi asumsi normalitas jika data menyebar di sekitar garis diagonal dan mengikuti arah garis diagonal. Jika data menyebar jauh dari garis diagonal dan/atau tidak mengikuti garis diagonal, maka model regresi tidak memenuhi asusi normalitas. Sebaran titik-titik pada Normal P-Plot of Regression Standardized Residual dari variabel terikat ditunjukkan pada Gambar 1.

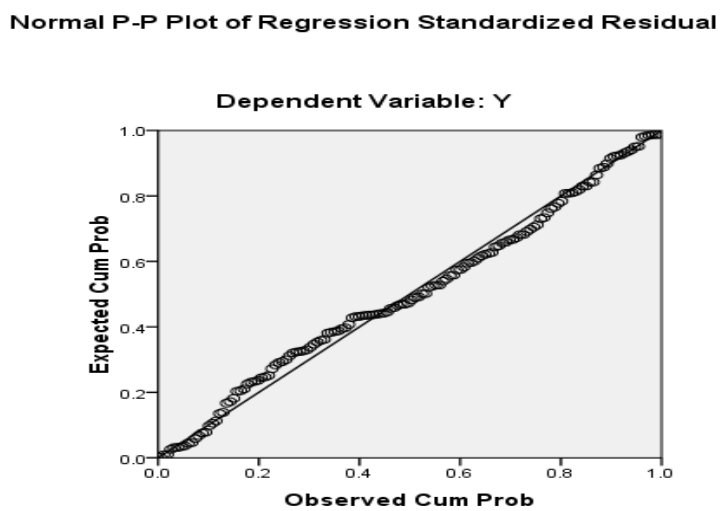

Gambar 1. Normal P-Plot of Regression Standardized Residual dari variabel terikat.

Berdasarkan gambar 1 dapat dilihat bahwa sebaran data berada di sekitar garis diagonal dan mengikuti arah garis diagonal sehingga dapat dikatakan bahwa data ini terdistribusi normal. Disamping itu untuk menguji data berdistribusi normal maka dilakukan uji Sample Kolmogorov-Smirnov dengan ketentuan jika nilai signifikansi (sig.) lebih besar dari 0,05 maka data penelitian berdistribusi normal sebaliknya jika nilai signifikansi lebih kecil dari 0,05 maka data penelitian tidak berdistribusi normal. Hasil uji Sample Kolmogorov-Smirnov dapat dilihat pada tabel 5. 
Tabel 5. Hasil Uji Sample Kolmogorov - Smirnov

\begin{tabular}{|ll|r|}
\hline & & \multicolumn{1}{|c|}{$\begin{array}{c}\text { Unstandardize } \\
\text { d Residual }\end{array}$} \\
\hline $\mathrm{N}$ & Mean & 144 \\
Normal & Std. & .000000 \\
Parameter & Deviation & 397.958 .871 \\
& & \\
Most Extreme & Absolute & .055 \\
Differences & Positive & .046 \\
Kolmogorov-Smirnov Z & -.055 \\
Asymp.Sig.(2-tailed) & .657 \\
\hline
\end{tabular}

Berdasarkan uji normalitas dengan metode Sample Kolmogorov - Smirnov diketahui nilai signifikansi mencapai 0,781 atau lebih besar dari 0.05 sehingga dapat dikatakan bahwa data penelitian ini berdistribusi normal.

\subsection{Uji Heteroskedatisitas}

Model regresi yang baik adalah tidak terjadi heterokedastisitas. Mendeteksi ada tidaknya heterokedastisitas dapat digunakan metode grafik Scatterplot yang dihasilkan dari output program SPSS. Berikut adalah grafik Scatterplot output program SPSS dari data penelitian.

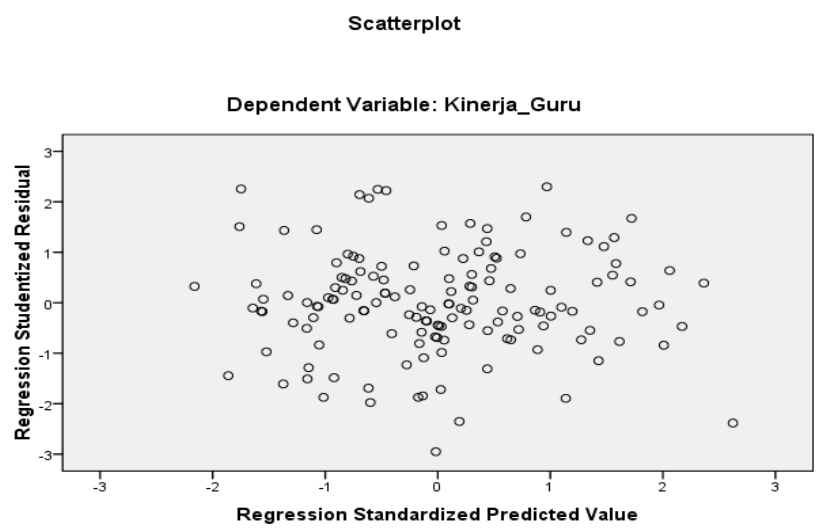

Gambar 2. Hasil Uji Heteroskedastisitas

Dari grafik tersebut terlihat titik-titik yang menyebar secara acak, tidak membentuk suatu pola tertentu yang jelas, serta tersebar baik di atas maupun dibawah angka 0 (nol) pada sumbu $Y$, hal ini berarti tidak terjadi penyimpangan asumsi klasik heterokedastisitas pada model regresi yang dibuat.

\subsection{Uji Multikolinieritas}

Sementara itu untuk mendeteksi ada atau tidaknya multikolinieritas, dapat dilakukan dari hasil output SPSS dengan melihat nilai tolerance dan Variance Inflation Factor (VIF). Nilai yang umum digunakan untuk mendeteksi adanya gejala multikolinieritas adalah jika tolerance $<0,1$ sedangkan VIF $>10$. Adapun hasil uji multikolinieritas pada penelitian ini adalah sebagai berikut. 
Tabel 6. Hasil Uji Multikolinieritas

\begin{tabular}{|c|c|c|c|}
\hline \multirow{2}{*}{\multicolumn{2}{|c|}{ Model }} & \multicolumn{2}{|c|}{ Collinearity Statistics } \\
\hline & & \multirow[t]{2}{*}{ Tolerance } & \multirow[t]{2}{*}{ VIF } \\
\hline \multirow{4}{*}{1} & (Constant) & & \\
\hline & $\begin{array}{l}\text { Kepemimpinan_Tr } \\
\text { ansformasional }\end{array}$ & .862 & 1.160 \\
\hline & Etos_Kerja & .770 & 1.298 \\
\hline & Kompetensi & .772 & 1.295 \\
\hline
\end{tabular}

Berdasarkan tabel 6 di atas diketahui bahwa nilai VIF semua variabel bebas dalam penelitian ini lebih kecil dari 10 sedangkan nilai toleransi semua variabel bebas lebih dari 0,10 . Hasil tersebut menunjukkan tidak terjadi korelasi antar variabel bebas, dengan demikian dapat disimpulkan bahwa tidak terdapat gejala multikolinieritas antar variabel bebas dalam model regresi.

\subsection{Uji Autokorelasi}

Uji asumsi klasik yang terakhir adalah uji autokorelasi. Uji autokorelasi pada penelitian ini dilakukan dengan menggunakan uji Durbin Watson. Hasil dari uji Durbin Watson pada penelitian ini dapat dilihat pada Tabel 7.

Tabel 7 Hasil Uji Durbin Watson

\begin{tabular}{|l|c|r|r|r|r|}
\hline Model & $\mathrm{R}$ & $\begin{array}{c}\mathrm{R} \\
\text { Square }\end{array}$ & $\begin{array}{r}\text { Adjusted } \\
\text { R Square }\end{array}$ & $\begin{array}{l}\text { Std. Error of } \\
\text { the Estimate }\end{array}$ & $\begin{array}{l}\text { Durbin- } \\
\text { Watson }\end{array}$ \\
\hline 1 & $.634^{\mathrm{a}}$ & .401 & .389 & 4.02200 & 1.830 \\
\hline
\end{tabular}

Berdasarkan tabel 7 dapat diketahui bahwa nilai Durbin Watson sebesar 1,830. Nilai $d_{L}$ dan $d_{U}$ dengan nilai signifikansi $(\alpha) 5 \%$, jumlah sample $144(n=144)$ dan jumlah variabel independen $3(\mathrm{k}=3)$ masing-masing sebesar 1.6854 dan 1.7704. Dengan demikian nilai Durbin Watson lebih besar dari nilai $\mathrm{d}_{\mathrm{U}}\left(\mathrm{DW} 1,830>\mathrm{d}_{\mathrm{U}}\right.$ 1.7704) dan DW kurang dari $\left(4-\mathrm{d}_{\mathrm{U}}\right)$ $4-1.7704=2.2296$ atau $1,7704<1,830<2,2296$ maka $\mathrm{H}_{0}$ diterima. Berdasarkan hasil tersebut dapat disimpulkan bahwa tidak terdapat autokorelasi pada model regresi yang akan dilakukan dalam penelitian ini.

\section{Analisis Regresi Linier Berganda}

Setelah uji asumsi klasik terpenuhi maka langkah selanjutnya untuk mengetahui besarnya pengaruh dari variabel terikat (independent) terhadap variabel bebas (dependent) pada Yayasan Tarbiyatul Islam NW Wanasaba Lombok Timur dapat dilakukan dengan analisis regresi berganda. Analisis regresi berganda pada penelitian ini terdiri dari uji $t$ dan uji F. Proses analisis regresi berganda tersebut menggunakan bantuan program software komputer yaitu SPSS.

\subsection{Uji t}

Uji $\mathrm{t}$ dilakukan untuk mengetahui pengaruh signifikan secara parsial antara kepemimpinan transformasional, etos kerja dan kompetensi terhadap kinerja guru pada Yayasan Tarbiyatul Islam NW Wanasaba Lombok Timur. Dalam pengujian ini dilakukan dengan uji $t_{\text {test }}$ dengan membandingkan antara $t_{\text {hitung }}$ dengan $t_{\text {tabel }}$ yang dapat dilihat pada tabel berikut: 
Tabel 8. Hasil Uji Regresi Linear Berganda Secara Parsial

\begin{tabular}{|l|c|c|c|}
\hline \multicolumn{1}{|c|}{ Model } & $\mathbf{t}$ & Sig. & Keterangan \\
\hline $\begin{array}{l}\text { Kepemimpinan_- } \\
\text { Transformasional }\end{array}$ & 4.749 & .000 & Signifikan \\
Etos_Kerja & 3.089 & .002 & $\begin{array}{l}\text { Signifikan } \\
\text { Signifikan }\end{array}$ \\
Kompetensi & 3.680 & .000 & . \\
\hline
\end{tabular}

Berdasarkan Tabel 8 dapat diketahui bahwa hasil pengujian hipotesis kepemimpinan transformasional, etos kerja, dan kompetensi menunjukan nilai thitung masing-masing sebesar $4.749,3.089$, dan 3.680 lebih besar dari nilai $t_{\text {tabel }}$ dengan a $0,05=1.65550$. Selain itu juga nilai probabilitas (signifikansi) variabel kepemimpinan transformasional, etos kerja, dan kompetensi sebesar 0,000 sehingga lebih kecil dari 0,05 yang berarti bahwa hipotesis observasi $\left(\mathrm{H}_{0}\right)$ ditolak dan menerima hipotesis alternatif $(\mathrm{Ha})$. Dengan demikian dapat disimpulkan bahwa kepemimpinan transformasional, etos kerja, dan kompetensi berpengaruh secara signifikan terhadap Kinerja Guru pada Yayasan Tarbiyatul Islam NW Wanasaba Lombok Timur.

Kemudian untuk mengetahui besarnya pengaruh dan hubungan antara variabel independent dan dependent dapat dilihat dari besarnya koefisien dari masing-masing variabel. Besarnya koefisiensi regresi dari ketiga variabel independent tehadapat variabel dependent dapat dilihat pada Tabel 9.

Tabel 8. Hasil Analisis Regresi Linier Berganda

\begin{tabular}{|l|l|l|l|l|l|l|}
\hline \multicolumn{2}{|c|}{ Model } & \multicolumn{2}{c|}{$\begin{array}{c}\text { Unstandardized } \\
\text { Coefficients }\end{array}$} & $\begin{array}{c}\text { Standardized } \\
\text { Coefficients }\end{array}$ & \multirow{2}{*}{ T } & \multirow{2}{*}{ Sig } \\
\cline { 2 - 5 } \multicolumn{2}{|c|}{ B } & Std. Error & Beta & & \\
\hline \multirow{2}{*}{1} & 1.119 & .304 & & 3.678 & .000 \\
\hline $\begin{array}{l}\text { (Constant) } \\
\text { Kepemimpinan } \\
\text { Transformasional (X1) }\end{array}$ & .305 & .064 & .335 & 4.749 & .000 \\
\cline { 1 - 4 } Etos Kerja (X2) & .169 & .055 & .230 & 3.089 & .002 \\
\hline Kompetensi (X3) & .251 & .068 & .274 & 3.680 & .000 \\
\hline
\end{tabular}

Kemudian pada Tabel 9 terlihat koefisiensi regresi dari Kepemimpinan transformasional, etos kerja, dan kompetensi masing-masing sebesar 0.305, 0.169, dan 0,251 dan memiliki arah positif. Hal ini menunjukkan bahwa apabila variabel kepemimpinan transformasional, etos kerja, dan kompetensi ditingkatkan secara parsial (terpisah) maka kinerja guru akan mengalami peningkatan. Begitu juga sebaliknya apabila variabel kepemimpinan transformasional, etos kerja, dan kompetensi ditingkatkan secara parsial (terpisah) turun maka kinerja guru akan menurun, dimana variabel lain dianggap tidak berubah atau konstan.

\section{$4.2 \mathrm{Uji} F$}

Uji simultan atau bersama-sama variabel independen terhadap variabel terikat dependen dapat diketahui dengan menggunakan uji F. Hasil uji regresi linear berganda secara simultan ditunjukan pada tabel 10. 
Tabel 10. Hasil Uji Regresi Linear Berganda Secara Simultan

\begin{tabular}{|c|l|r|r|r|r|r|}
\hline \multicolumn{2}{|c|}{ Model } & $\begin{array}{r}\text { Sum of } \\
\text { Squares }\end{array}$ & Df & $\begin{array}{r}\text { Mean } \\
\text { Square }\end{array}$ & \multicolumn{1}{c|}{ F } & Sig. \\
\hline \multirow{2}{*}{1} & Regression & 4.696 & 3 & 1.565 & 31.3 & .00 \\
& & & & 33 & $0^{\mathrm{b}}$ \\
\cline { 2 - 7 } & Residual & 6.995 & 140 & .050 & & \\
\cline { 2 - 7 } & Total & 11.691 & 143 & & & \\
\hline
\end{tabular}

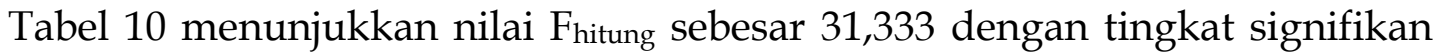
0,000. Menggunakan tingkat keyakinan 95\%, dengan taraf signifikansi 5\% $(\alpha=5 \%)$ dan derajat kebebasan df1 = k-1, dan df2 = n-k sehingga df1 (4 - 1) = 3 dan df2 (144 $4)=140$. Dari empat variabel penelitian dengan jumlah data sebanyak 144 dan taraf signifikansi 5\% maka diperoleh nilai $\mathrm{F}_{\text {tabel }}$ sebesar 2,67.

Berdasarkan data di atas maka dapat diketahui bahwa $\mathrm{F}_{\text {hitung }}$ lebih besar dari $\mathrm{F}_{\text {tabel }}$ $(31,333>2,67)$. Hal ini menunjukkan bahwa secara simultan atau secara bersama-sama varibel kepemimpinan transformasional, etos kerja dan kompetensi berpengaruh terhadap kinerja guru Yayasan Tarbiyatul Islam NW Wanasaba Lombok Timur.

\section{KESIMPULAN DAN SARAN}

\section{A. Kesimpulan}

Berdasarkan hasil yang diperoleh dapat disimpulkan bahwa :

1. Secara parsial (terpisah) ketiga variabel indendendent (Kepemimpinan transformasional, etos kerja, dan kompetensi) berpengaruh secara signifikan terhadap Kinerja Guru pada Yayasan Tarbiyatul Islam NW Wanasaba Lombok Timur. Ketiga variabel indendendent tersebut memiliki pengaruh yang berbanding lurus terhadap kinerja guru. Dengan demikian apabila variabel kepemimpinan transformasional, etos kerja, dan kompetensi ditingkatkan secara parsial (terpisah) maka kinerja guru akan mengalami peningkatan. Begitu juga sebaliknya apabila variabel kepemimpinan transformasional, etos kerja, dan kompetensi ditingkatkan secara parsial (terpisah) turun maka kinerja guru akan menurun, dimana variabel lain dianggap tidak berubah atau konstan.

2. Secara simultan atau secara bersama-sama ketiga variabel bebas (independent) yang terdiri dari kepemimpinan transformasional, etos kerja dan kompetensi berpengaruh terhadap kinerja guru Yayasan Tarbiyatul Islam NW Wanasaba Lombok Timur. Dengan demikian peningkatan kepemimpinan transformasional, etos kerja dan kompetensi Guru pada Yayasan Tarbiyatul Islam NW Wanasaba Lombok Timur secara bersama-sama akan berdampak pada peningkatan Kinerja Guru pada Yayasan Tarbiyatul Islam NW Wanasaba Lombok Timur.

\section{B. Saran}

Untuk meningkatkan informasi mengenai factor-faktor yang mempengaruhi kinerja guru dimasa yang akan datang, peneliti menyarankan :

1. Menambah variabel independent yang mempengaruhi kinerja guru seperti fasilitas sekolah.

2. Melibatkan faktor di luar guru dan sekolah yaitu berupa kemauan dan kesadaran siswa untuk sekolah dan belajar.

3. Menambahkan juga variabel independent berupa keuangan (tingkat ekonomi) dari guru beserta indikator-indikator dari keuangan guru sebagai penunjang kinerja guru. 


\section{DAFTAR PUSTAKA}

Aminatuzzuhro, Gunadi (2017), “ Pengaruh Disiplin dan Kompetensi terhadap Kinerja Guru di Madrasah Tsanawiyah Ittihadul Ulum Kota Lubuklinggau", Interprof (Jurnal Manajmen), III, 39 - 59

Atmojo, Y.E. (2018) Kepemimpinan Transformasional Kepala Sekolah, Salatiga: Griya Media

Ghozali. I. (2001). Aplikasi Analisis Multivariate dengan Program SPSS, BP UNDIP, Semarang.

Ghozali, I (2005), Aplikasi Analisis Multivariate dengan Menggunakan SPSS, Semarang: Badan Penerbit Universitas Diponegoro.

Hakim, H., (2017), “Pengaruh Etos Kerja dan Disiplin Kerja terhsdsp Efektivitas Kerja Guru di SMK Teknik Dipanegara Tebing Tinggi", Wahana Inovasi, Vol. 6 (2), 340 - 348

Heriswanto, (2018), "Pengaruh kompetensi Guru terhadap Kinerja Guru SMPN I Lambuya Kab Konawe Melalui Motivasi Kerja Sebagai Vriabel Intervening", Jurnal Aksara Publik, Vol 2 (3), 136 - 152

Heryana, M., (2015), “Kepemimpinan Transformasional, Motivasi Kerja Guru dan kompetensi Guru terhadap Kinerja Guru Serta Implikasinya Pada Kompetensi Lulusan", Kontigensi, Vol 3 (1), $44-67$

Hidayati, E (2018), “Analisis Pengaruh Supervisi dan Kompetensi terhadap Kinerja Guru SMP Negeri 1 Bekasi Tahun Ajaran 2016/2017", Jurnal Sekolah Dasar; Elementary School Journal, 1 (3), 1 - 10

Karim, M (2010) Pemimpin Transformasional di Lembaga Pendidikan Islam, Malang: UIN Maliki Press.

Marlina, (2015), “Pengaruh Motivasi, Disiplin, dan Etos Kerja terhadap Kinerja Guru SLTA Negeri di Kecamatan Baolan Kabupaten Tolitoli", e-Jurnal Katalogis, Volume 3 Nomor 7, 153-162

Northouse, P.G (2013) Kepemimpinan Teori dan Praktik Edisi Keenam, Jakarta: Indeks

Nurdianti, R.R.S., (2017), "Pengaruh Kompetensi Profesional dan Kompetensi Pedagogik terhadap Kinerja Guru Ekonomi SMA Negeri di Kota Bandung", Jurnal Ilmiah Manajmen \& Bisnis, XVIII (2), 177 - 188

Putra R.A.C, Dedi P, Corry Y, (2017) “ Gaya Kepemimpinan Transformasional Kepala Sekolah dan Kinerja Guru SMK Swasta di Jakarta Timur", Jurnal Pendidikan Ekonomi \& Bisnis 5 (2) 2017148 - 161

Patarai, I., Mustari, Azis, M., (2018), “Motivasi Mengajar, Kompetensi Profesional dan Tingkat Pendidikan terhadap Kinerja Guru”, Jurnal Mirai Management, Vol. 3 (2), $120-133$

Priansa. D.J (2014) Kinerja dan Profesionalisme Guru, Bandung: Alfabeta

Putra, CAA., Yudana, M., Natajaya, N., (2013), "Hubungan Motivasi Berprestasi, Prilaku Kepemimpinan Kepala Sekolah dan Etos Kerja dengan Kinerja Guru di SMA N 1 Kubutambahan", e-Journal Program Pascasarjana Universitas Pendidikan Ganesha Program Studi Administrasi Pendidikan, Vol. 4, xx - xx

Ridwan and Kuncoro, E.A. (2008), Organisasi, Perilaku Struktur Proses, Jakarta: Binarupa Aksara

Rustamaji, ACP., Purwana, D., Yohana, C. (2017), “Gaya Kepemimpinan Transformasional Kepala Sekolah dan Kinerja Guru SMK Swasta di Jakarta Timur", Jurnal Pendidikan \& Bisnis, 5 (2), 148 - 161

Suandi, I.N., (2018), “Pengaruh Kedisiplinan, Motivasi, dan Kompetensi Guru terhadap Kinerja Guru Pada SMK Nusa Dua Toya Anyar", Widyadari, Vol 9 (1), 109 - 135

Sugiyono (2016), Metode Penelitian dan Pengembangan \& RD, Bandung: Alfabeta 
Sukardewi, N., Dantes, N., Natajaya, N.,(2013), “Kontribusi Adversity Quotient (AQ), Etos Kerja, dan Budaya Organisasi terhadap Kinerja Guru SMA Negeri di Kota Amlapura", e-Jurnal Program Pascasarjana Universitas Pendidikan Ganesha Program Studi Pendidikan Dasar, Vol. 4, xx - xx

Supardi (2012), Kinerja Guru, Jakarta: Raja Grafindo Persada

Tasmara, T. (2002), Membudayakan Etos Kerja Islami, Jakarta: Gema Insani.

Turangan, J.K., (2017), “Pengaruh Kompetensi, Disiplin Kerja, dan Profesionalisme terhadap Kinerja Guru di SMA Negeri 1 Manado", Jurnal EMBA, Vol. 5 No 2, 1402 - 1411

Tokhibin \& Wuradji, (2013) "Pengaruh Kepemimpinan Transformasional Kepala Sekolah, Kompetensi, Motivasi dan Kedisiplinan Guru terhadap Kinerja Guru SMK", Jurnal Akuntabilitas Manejmen Pendidikan, 1 (2), 308 -320

Waang, M., Matin, Ahmad,M., (2019), "Pengaruh Efektivitas Manajerial Kepala Sekolah dan Etos Kerja Terhadap Kinerja Guru Sekolah Dasar di Kecamatan Teluk Mutiara Kabupaten Alor", Jurnal Ilmiah Wahana Pendidikan Vol 5, No., 98 - 105

Wibowo. (2014). Manajemen Kinerja-Edisi keempat. Jakarta: PT. Raja grafindo Persada

Wiriani, M., Dantes, N., Sudiana, N., (2013), “Hubungan Perilaku Kepemimpinan Kepala Sekolah, Etos Kerja Guru dan Budaya Organisasi terhadap Kinerja Guru Sekolah Dasar", e-Jurnal Program Pascasarjana Universitas Pendidikan Ganesha Program Studi Pendidikan Dasar, Vol. 3, xx - xx

Yuliati, (2015), "Pengaruh Kepemimpinan Transformasional dan Kepuasan Kerja terhadap Kinerja dengan Komitmen Organisasi sebagai Variabel Mediasi (Studi Empiris Pada SMK Swasta Kecamatan Gayamsari Semarang)", Prosiding Seminar Nasional \& Call For Papers, Vol. xx, No. xx, 69 - xx

Yusuf, D.U., (2017), “Analisis Keterampilan Manajerial, dan Gaya Kepemimpinan Transformasional Kepala Sekolah terhadap Kinerja Guru di SMPN 2 Pattallangssang Gowa", UNM Journal of Technology and Vocational, Vol. 1 No 2, $\mathrm{xx}-\mathrm{xx}$ 